\title{
Blood Pressure, Renin Activity and Heart Rate Changes During Propranolol Therapy of Hypertension
}

\author{
ANDREW ZWEIFLER, MD \\ MURRAY ESLER, MB, PhD
}

Ann Arbor, Michigan
From the Division of Hypertension, Department of Internal Medicine, University of Michigan Medical Center, Ann Arbor, Michigan. This work was supported in part by grants from Ayerst Laboratories, New York, New York and the Michigan Heart Association, Southfield, Michigan, and by Grant 5-MO1-RR42 from the U. S. Public Health Service, Bethesda, Maryland, to the Clinical Research Unit, University of Michlgan Medical Center. Manuscript received November 17, 1976; revised manuscript received January 18, 1977 accepted February 16, 1977.

Address for reprints: Andrew J. Zweifler, MD, B 4952 Clinical Faculty Office Building. University of Michigan Medical Center, Ann Arbor, Michigan 48109.
To investigate the importance of plasma renin activity in determining the antihypertensive action of propranolol and of heart rate in guiding propranolol therapy, the effect of a graded oral dose of propranolol on blood pressure, plasma renin and heart rate was studied in 24 men with essential hypertension and differing initial levels of renin activity. Although plasma renin decreased substantially in patients with normal and high renin levels taking a small dose of propranolol ( $40 \mathrm{mg} /$ day), blood pressure was unchanged in the normal renin group, and a small decrease in systolic pressure alone was noted in those with high plasma levels of renin. Patients with low renin levels had no reduction in blood pressure with small doses of propranolol, but as a group they responded well to a dose of $\mathbf{3 2 0}$ $\mathrm{mg} /$ day. Standing heart rate decreased maximally at plasma propranolol concentrations greater than $25 \mathrm{ng} / \mathrm{ml}$, and did not exceed 72 beats/min with plasma concentrations above that level. Overall, the observed responses for plasma renin and heart rate were more pronounced at lower plasma propranolol concentrations than those for blood pressure.

The beta adrenergic receptor blocking agent propranolol is an effective antihypertensive agent. ${ }^{1}$ The mechanism of this action has been vigorously pursued, with the major sites of interest being the heart, ${ }^{2}$ the brain $^{3}$ and the kidney. The latter has received considerable attention, primarily because of the work of Bühler, Laragh and associates. ${ }^{4}$ Building on the fact that renin release is inhibited by propranolol ${ }^{5}$ and the assumption that angiotensin II is a major factor in determining peripheral resistance in patients with hypertension, these investigators have postulated that propranolol reduces blood pressure because it decreases renin activity. They suggest, as a corollary, that the level of renin activity in a given hypertensive patient is an important predictor of responsiveness to propranolol. ${ }^{4}$ However, Hansson and Zweifler ${ }^{6}$ observed that although plasma renin activity decreased substantially in a group of patients treated with propranolol, $320 \mathrm{mg} / \mathrm{day}$, blood pressure reduction was not invariable. Other studies have also raised serious doubts that propran$\mathrm{olol}^{7}$ and other beta adrenergic blocking drugs ${ }^{8,9}$ are antihypertensive because of their effect on plasma renin activity. The present study was designed to compare changes in plasma renin, heart rate and blood pressure produced by small doses of propranolol as well as a dose of 320 $\mathrm{mg} /$ day in a group of hypertensive patients with differing initial levels of renin activity.

\section{Material and Methods}

Study population: Twenty-four patients with essential hypertension were recruited from the hypertension clinics of the University of Michigan Medical Center and the University of Michigan Health Service. All were men aged 20 to 60 years and had casual clinic-recorded blood pressures greater than $150 \mathrm{~mm}$ $\mathrm{Hg}$ systolic or $90 \mathrm{~mm} \mathrm{Hg}$ diastolic, or both, after at least 2 weeks of no medication other than placebo. Patients with diastolic pressure greater than $125 \mathrm{~mm} \mathrm{Hg}$, grade III or IV retinopathy, or serum creatinine concentration greater than 2.0 


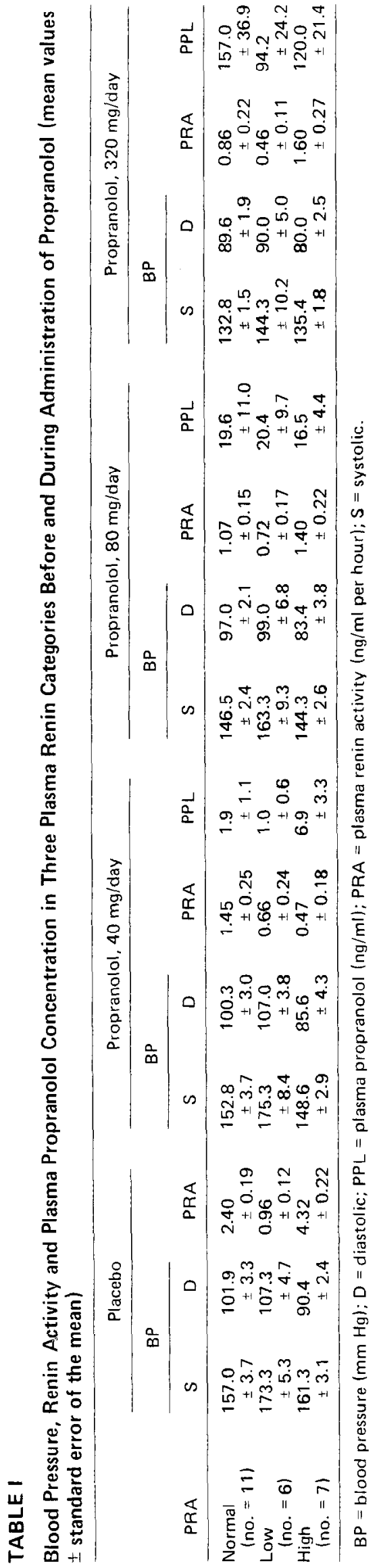

$\mathrm{mg} / 100 \mathrm{ml}$ were not considered for the study. Secondary causes of hypertension were excluded by thorough clinical examination and laboratory studies including rapid sequence intravenous urography and measurement of urinary aldosterone excretion.

All patients were told of the investigative nature of the study and read and signed a consent form outlining the details of the tests to be performed.

Renin categorization: A 24 hour urinary sample for determination of sodium was collected in a metabolic ward after the patient had been maintained on a $160 \mathrm{mEq}$ sodium diet for at least 5 days. Blood for plasma renin estimation was drawn in the morning after 1 hour of standing. Plasma was separated in a refrigerated centrifuge, stored at $-20^{\circ} \mathrm{C}$, and plasma renin activity was estimated within 2 months by radioimmunoassay. ${ }^{10}$ A nomogram relating plasma renin activity during standing to 24 hour urinary sodium excretion ${ }^{11}$ was developed from measurements in 41 age-matched normal male volunteers. Patients were categorized into normal, high and low renin groups by referring their plasma renin values to the limits of normality defined by the nomogram. In patients with low plasma renin, renin activity subsequently remained suppressed after 6 days of sodium deprivation (10 $\mathrm{mEq}$ sodium daily). Plasma renin activity was elevated in 7 patients, normal in 11 and low in 6 . This distribution was a consequence of selective recruitment for the study, based on previous plasma renin typing, in an effort to obtain an adequate number of patients in each renin subgroup.

Drug trial: Patients were given placebo for 2 weeks, then given propranolol in the following doses: $10 \mathrm{mg}$ four times daily for 4 weeks, $20 \mathrm{mg}$ four times daily for 4 weeks and $80 \mathrm{mg}$ four times daily for 4 weeks. At the end of each treatment period patients returned in the morning, were examined and had blood drawn after 1 hour of standing for determination of plasma renin activity and plasma propranolol level (2 to 3 hours after the last dose of propranolol). Plasma propranolol concentration was measured fluorometrically.*12 Blood pressure and pulse rate were determined on each visit by the same observer (M.E.) after 3 minutes of recumbency and 1 minute of standing.

\section{Results}

Blood pressure response and renin activity: During placebo therapy, patients with low plasma renin had a slightly higher mean blood pressure $(P<0.05$; (analysis of variance [Sheffé method]) than those in the other two renin categories (Table I) and those in the high plasma renin group had lower mean and diastolic pressures $(P<0.05)$. Treatment with propranolol in a dose of $40 \mathrm{mg} /$ day caused no significant reduction of blood pressure in patients with a normal or low renin level, but systolic blood pressure decreased $(P<0.01$, paired $t$ test) in the high renin group (Fig. 1). Propranolol in a dose of $80 \mathrm{mg} /$ day produced a significant decrease in blood pressure in patients with normal renin and a further reduction in those with high plasma renin but had no effect in the low renin group. A substantial reduction in blood pressure occurred in patients in all three renin categories during treatment with propranolol in a dose of $320 \mathrm{mg} /$ day.

Plasma renin activity (Table I) decreased significantly $(P<0.01$, paired $t$ test) and substantially during administration of propranolol, $40 \mathrm{mg} / \mathrm{day}$, in patients

\footnotetext{
* Courtesy of Ayerst Laboratories.
} 


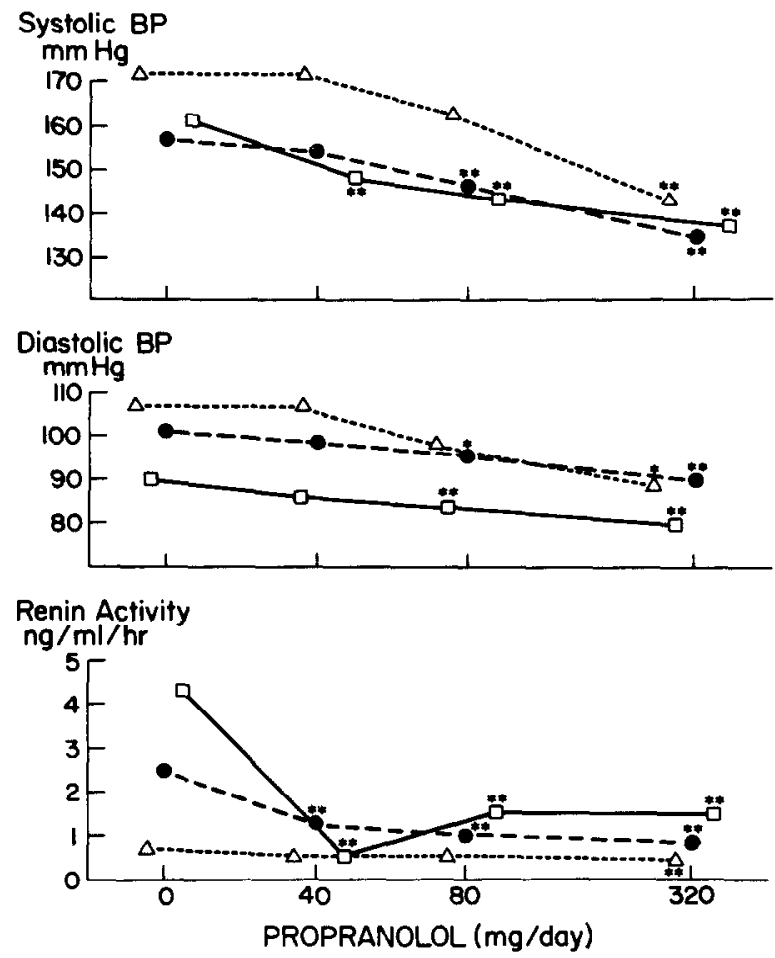

FIGURE 1. Changes in recumbent blood pressure (BP) and upright plasma renin activity during propranolol therapy in three renin categories: low renin (triangles) (no. $=6$ ); normal renin (closed circles) (no. $=11$ ); high renin (squares) (no. $=7$ ). Significance of change from control value (paired $t$ test): $*=P$ (probability) $<0.05 ; \cdots=P$ $<0.01$.

with a normal or high renin level. Larger doses of the drug were accompanied by a further decrease in renin activity in patients in the normal renin group, but an increase in renin levels in patients in the high renin group (Fig. 1). In the low renin group, renin activity decreased significantly only at the dose of $320 \mathrm{mg} /$ day.

A positive correlation between change in blood pressure and change in plasma renin activity during treatment with propranolol in a dose of $40 \mathrm{mg} /$ day was observed only in the high renin group, and in this group the linear correlation coefficient was only $0.34(P>0.05)$. A statistically significant correlation between reduction in blood pressure and decrease in renin activity also was not found in any of the patient groups during the 80

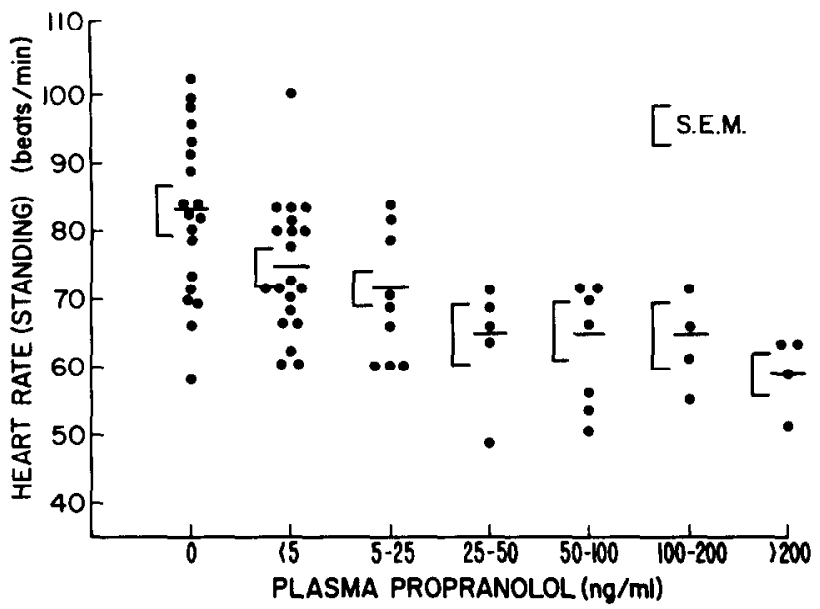

FIGURE 2. Standing heart rate before and during propranolol therapy related to plasma propranolol concentration. S.E.M. = standard error of the mean.

$\mathrm{mg} /$ day treatment period. At $320 \mathrm{mg} /$ day the correlation coefficients were as follows: normal renin $0.41(P>$ $0.05)$, low renin $0.34(P>0.05)$ and high renin $0.78(P$ $<0.05$ ). Plasma propranolol concentrations were similar in all three renin subsets at the various administered doses of the drug (Table I); although the concentrations ranged from 1 to $6.9 \mathrm{ng} / \mathrm{ml}$ during administration of propranolol $(40 \mathrm{mg} /$ day $)$, the differences between groups were not statistically significant.

Heart rate response and renin activity: Heart rates in the normal and low renin groups were similar, and were slower than in patients with high renin activity (Table II), but this difference was statistically significant $(P<0.05)$ only for standing heart rate. Propranolol in a dose of $40 \mathrm{mg} /$ day had no significant effect on heart rate in patients with low renin activity but had a dramatic effect on those with a high renin activity; the normal renin group demonstrated a moderate response. Further slowing of the heart was observed in the high and normal renin groups during treatment with 80 $\mathrm{mg} /$ day. In a dose of $320 \mathrm{mg} /$ day propranolol produced cardiac slowing in all patients, and heart rates in all renin groups were similar at the end of this treatment period. Standing heart rate paralleled propranolol dose more closely than recumbent heart rate, particularly in the normal renin group. Definite cardiac slowing was

\section{TABLE ॥}

Supine and Standing Heart Rates in Three Plasma Renin Categories Before and During Administration of Propranolol (mean values \pm standard error of the mean)

\begin{tabular}{|c|c|c|c|c|c|c|c|c|}
\hline \multirow[b]{2}{*}{ PRA } & \multicolumn{2}{|c|}{ Placebo } & \multicolumn{2}{|c|}{ Propranolol, $40 \mathrm{mg} / \mathrm{day}$} & \multicolumn{2}{|c|}{ Propranolol, $80 \mathrm{mg} / \mathrm{day}$} & \multicolumn{2}{|c|}{ Propranolol, $320 \mathrm{mg} / \mathrm{day}$} \\
\hline & $\begin{array}{c}\text { Supine } \\
\text { HR }\end{array}$ & $\begin{array}{c}\text { Standing } \\
H R\end{array}$ & $\begin{array}{l}\text { Supine } \\
\text { HR }\end{array}$ & $\begin{array}{c}\text { Standing } \\
\mathrm{HR}\end{array}$ & $\begin{array}{c}\text { Supine } \\
\text { HR }\end{array}$ & $\begin{array}{c}\text { Standing } \\
H R\end{array}$ & $\begin{array}{l}\text { Supine } \\
\text { HR }\end{array}$ & $\begin{array}{c}\text { Standing } \\
\mathrm{HR}\end{array}$ \\
\hline $\begin{array}{l}\text { Normal }(\text { no. }=11) \\
\text { Low (no. }=6) \\
\text { High }(\text { no. }=7)\end{array}$ & $\begin{array}{l}71.1 \pm 3.9 \\
63.8 \pm 4.7 \\
79.1 \pm 3.4\end{array}$ & $\begin{array}{l}82.9 \pm 3.8 \\
79.8 \pm 5.2 \\
96.6 \pm 4.0\end{array}$ & $\begin{array}{l}66.0^{*} \pm 3.0 \\
63.0 \pm 3.9 \\
63.4^{\dagger}+1.9\end{array}$ & $\begin{array}{l}74.9^{*} \pm 4.1 \\
72.0^{ \pm} \pm 5.1 \\
75.0^{\dagger} \pm 2.1\end{array}$ & $\begin{array}{l}64.9^{*} \pm 2.8 \\
58.8 \pm 3.7 \\
59.4^{\dagger} \pm 1.9\end{array}$ & $\begin{array}{l}70.8^{\dagger} \pm 3.6 \\
69.9 \pm 4.0 \\
69.3^{\dagger} \pm 2.9\end{array}$ & $\begin{array}{l}56.4^{\dagger} \pm 2.2 \\
53.5^{\dagger} \pm 2.4 \\
56.7^{\dagger} \pm 2.6\end{array}$ & $\begin{array}{l}59.9^{\dagger} \pm 2.8 \\
57.3^{\dagger} \pm 3.1 \\
62.9^{+} \pm 1.8\end{array}$ \\
\hline
\end{tabular}

${ }^{*} P<0.05 ;{ }^{\dagger} P<0.01$ (significant change from placebo value [paired $t$ test])

$\mathrm{HR}=$ heart rate; $P=$ probabilitv; $\mathrm{PRA}=$ plasma renin activity. 


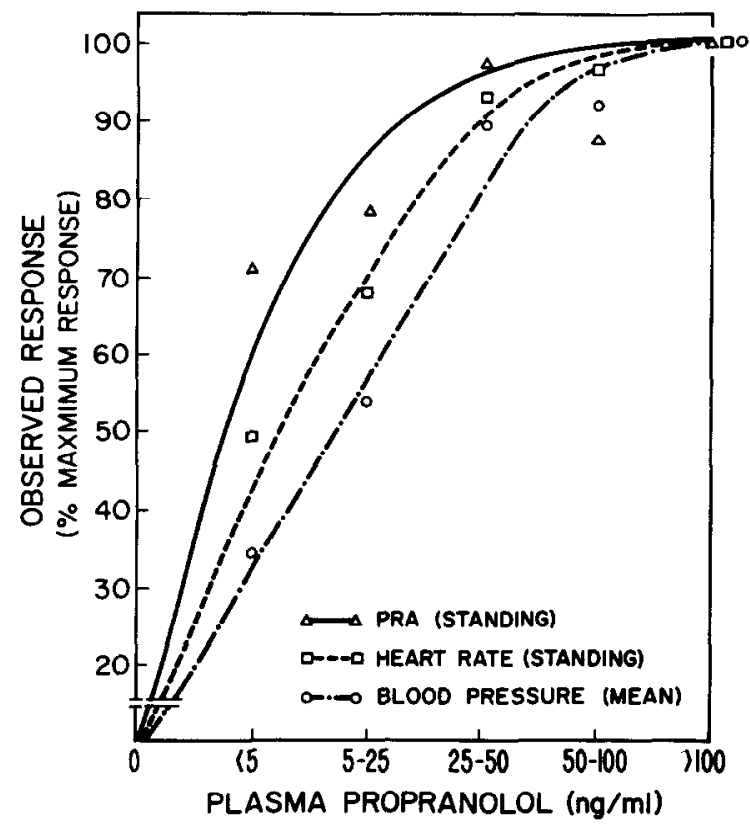

FIGURE 3. Percent of maximal observed response of blood pressure, plasma renin activity (PRA) and heart rate related to plasma propranolol concentration.

apparent at very low plasma propranolol levels and a maximal effect was achieved with concentrations of 25 to $50 \mathrm{ng} / \mathrm{ml}$ (Fig. 2). A standing heart rate greater than 72 beats/min was not observed with a plasma propranolol concentration greater than $25 \mathrm{ng} / \mathrm{ml}$.

Correlation with propranolol plasma levels: When expressed as percent of maximal observed response, blood pressure achieved 37 percent of its total change during propranolol therapy at plasma propranolol levels of less than $5 \mathrm{ng} / \mathrm{ml}$ (Fig. 3). By contrast, the plasma renin response was 78 percent of maximum at a plasma propranolol level of less than $5 \mathrm{ng} / \mathrm{ml}$ and the heart rate response was 49 percent of maximum at the same plasma level. The dose-response curves for plasma renin and heart rate became almost flat with concentrations of 25 to $50 \mathrm{ng} / \mathrm{ml}$, as did the blood pressure curve with concentrations of 50 to $100 \mathrm{ng} /$ $\mathrm{ml}$.

\section{Discussion}

Correlation of plasma renin levels and blood pressure response to propranolol: The results of this study reveal a dissociation between change in blood pressure and change in plasma renin activity during administration of small doses of propranolol to patients with essential hypertension. Renin activity did decrease substantially in patients with normal and high renin levels taking propranolol in a dose of $40 \mathrm{mg} /$ day. How ever, blood pressure did not decrease in the normal renin group, and only a modest decrease in systolic pressure was observed in patients with a high plasma renin level; and within the latter group, the correlation between change in blood pressure and change in plasma renin activity was not statistically significant. These findings therefore tend to refute the hypothesis ${ }^{4}$ that propranolol decreases blood pressure because it decreases renin activity and are consistent with earlier ${ }^{5}$ and more recent ${ }^{13}$ findings. The differing dose-response relations of blood pressure, plasma renin and heart rate to plasma propranolol concentration are additional evidence against the "renin hypothesis" and add weight to the similar finding of Leonetti et al. ${ }^{14}$ Our data differ from those of Hollifield et al., ${ }^{15}$ who observed a decrease in blood pressure in normal renin hypertensive patients taking propranolol in a dose of $40 \mathrm{mg} /$ day, with a significant correlation between change in pressure and change in renin activity at that dose. This discrepancy is unexplained, but perhaps is due to differences in case selection or renin categorization. Nevertheless, it is difficult to accept the interpretation of Hollifield et al. of their results during small dose propranolol therapy. The degree of correlation they observed was not high enough to establish a cause and effect relation between blood pressure reduction and decrease in plasma renin activity.

Our study lends some support to those who believe that renin activity may have some value in predicting the antihypertensive response to propranolol therapy, ${ }^{4,14}$ but only at low dose levels. Blood pressure decreased modestly in patients with a high renin level taking propranolol in a dose of $40 \mathrm{mg} /$ day and not at all in patients with a low or normal renin level given the same dose. This difference is probably related to the fact that our high renin group represents a special subset of patients with essential hypertension who have increased sympathetic nervous system activity. ${ }^{16}$ Nevertheless, it is important to point out that blood pressure decreased substantially in all three groups of patients when taking $320 \mathrm{mg} /$ day of propranolol. This latter observation is compatible with previous data ${ }^{15,17}$ and consistent with the concept that propranolol is capable of decreasing blood pressure through some mechanism other than suppression of the renin-angiotensin system.

Correlation of plasma renin levels and heart rate response to propranolol: The data relating change in heart rate to dose of propranolol reveal that (1) substantial cardiac slowing occurs with a small dose of propranolol in patients with normal and high renin activity; (2) cardiac slowing in patients with normal and high renin activity is related to the dose of propranolol administered; and (3) patients with high renin activity are more sensitive and those with low renin activity less sensitive to the chronotropic effects of propranolol than those with normal renin activity. This finding may be related to diminished sympathetic nervous system activity in those with a low renin level ${ }^{18}$ and to heightened activity in the high renin group. 16

Plasma propranolol concentrations of more than 25 $\mathrm{ng} / \mathrm{ml}$ were always accompanied by standing heart rates of less than 72 beats $/ \mathrm{min}$. Because the dose-response curve for change in heart rate in relation to plasma propranolol concentration is to the left of that seen with 
change in blood pressure (that is, slowing of heart rate occurs at a lower plasma propranolol concentration than that causing a decrease in blood pressure), absence of a heart rate effect in patients with a suboptimal blood pressure response during propranolol therapy indicates inadequate plasma levels of propranolol. If blood pressure has not normalized during treatment with propranolol alone and the standing heart rate is greater than $72 / \mathrm{min}$, the dose of propranolol should be increased.

\section{References}

1. Zacharlas FJ, Cowen KJ, Presst J, et al: Propranolol in hypertension: a study of long-term therapy, 1964-1970. Am Heart J 83:755-761, 1972

2. Tarazi RC, Dustan HP: Beta-adrenergic blockade in hypertension. Am J Cardiol 29:633-640, 1972

3. Lewis P: The essential action of propranolol in hypertension. Am J Med 60:837-852, 1976

4. Bühler FR, Laragh JH, Baer $L$, et al: Propranolol inhibition of renin secretion. N Engl J Med 287:1209-1214, 1972

5. Michelakis AM, McAllister RG: The effect of chronic adrenergic receptor blockade on plasma renin activity in man. J Clin Endocrinol Metab 34:386-394, 1972

6. Hansson L, Zwelfier AJ: The effect of propranolol on plasma renin activity and blood pressure in mild essential hypertension. Acta Med Scand 195:397-401, 1974

7. Bravo EL, Tarazi RC, Dustan HP: $\beta$-adrenergic blockade in diuretic-treated patients with essential hypertension. $N$ Engl J Med 292:66-70, 1975

8. Esler MD: Effect of practolol on blood pressure and renin release in man. Clin Pharmacol Ther 15:484-489, 1974

9. Morgan TO, Sabte J, Anavekor SN: A comparison of beta-adrenergic blocking drugs in treatment of hypertension. Postgrad Med J 50:253-259, 1974

10. Haber E, Koerner T, Page LB, et al: Application of a radioimmunoassay for angiotensin I to the physiologic measurements of plasma renin activity in normal human subjects. $J$ Clin Endocrinol
Metab 29:1349-1355, 1969

11. Laragh JH: Vasoconstriction-volume analysis for understanding and treating hypertension: the use of renin and aldosterone profiles. Am J Med 55:261-274, 1973

12. Shand DG, Nuckolls EM, Oates JA: Plasma propranolol levels in adults, with observations in four children. Clin Pharmacol Ther 11:112-120, 1970

13. Morgan TO, Roberts R, Carney SC, et al: Beta-adrenergic receptor blocking drugs, hypertension and plasma renin. $\mathrm{Br} \mathrm{J}$ Clin Pharmacol 2:159-168, 1975

14. Leonetti G, Mayer G, Morganti A, et al: Hypotensive and reninsuppressing activities of propranolol in hypertensive patients. Clin Sci Mol Med 48:491-499, 1975

15. Hollifield JW, Sherman K, VanderZwagg R, et al: Proposed mechanisms of propranolol's antihypertensive effects in essential hypertension. N Engl J Med 294:68-73, 1976

16. Esler M, Julius S, Zweifler A, et al: Mild high renin essential hypertension: neurogenic human hypertension? N Engl J Med 296: 405-411, 1977

17. Woods JW, Pittman AW, Pulliam CC, et al: Renin profiling in hypertension and its use in treatment with propranolol and chlorthalidone. N Engl J Med 294:1137-1143, 1976

18. Esler M, Zweifler A, Randall $O$, et al: Suppression of sympathetic nervous function in low-renin essential hypertension. Lancet 2 : $115-118,1976$ 